\title{
Thiopurine methyltransferase enzyme activity determination before treatment of inflammatory bowel disease with azathioprine: Effect on cost and adverse events
}

\author{
Farzana A Sayani BSc MD ${ }^{1}$, Connie Prosser $\mathrm{PhD}^{2}$, Robert J Bailey MD FRCPC ${ }^{1}$, \\ Philip Jacobs DPhil ${ }^{3}$, Richard N Fedorak MD FRCPC ${ }^{1}$
}

\begin{abstract}
FA Sayani, C Prosser, RJ Bailey, P Jacobs, RN Fedorak. Thiopurine methyltransferase enzyme activity determination before treatment of inflammatory bowel disease with azathioprine: Effect on cost and adverse events. Can J Gastroenterol 2005;19(3):147-151.
\end{abstract}

BACKGROUND: Azathioprine (AZA), used to treat inflammatory bowel disease (IBD), is metabolized by thiopurine methyltransferase (TPMT). The accumulation of individual metabolites varies because humans display genetic polymorphism for TPMT expression. Deficiencies in TPMT result in accumulation of toxic metabolites, followed by neutropenia and hepatic inflammation. Concern over acute toxicity frequently leads to under dosing and frequent monitoring tests and visits.

OBJECTIVE: To determine whether assessment of TPMT activity before the administration of AZA would predict acute toxicity and, thus, allow for reductions in health care costs related to biochemical screening for, and management of, AZA-induced adverse events. METHODS: Before AZA treatment, 29 patients with IBD were prospectively randomized to one of two groups: group 1, in which no TPMT assay was performed, was started on AZA at $1 \mathrm{mg} / \mathrm{kg} / \mathrm{day}$ and then titrated every two weeks to a target dose of $2.5 \mathrm{mg} / \mathrm{kg} /$ day; and group 2, in which TPMT assays were performed, was started on AZA at the target dose of $2.5 \mathrm{mg} / \mathrm{kg} /$ day. For both groups, complete blood count and liver enzymes were monitored weekly for six weeks and at monthly intervals thereafter. Additional tests and health care interventions were undertaken at the discretion of the attending physicians. RESULTS: Of the 29 patients in the study, 15 were randomly assigned to group 1 and 14 to group 2. Demographics and disease activity were similar for both groups. Mean follow-up time was 7.1 months (range 3.5 to 10.7 months). Eight patients from group 1 and six patients from group 2 withdrew as a result of AZA-induced adverse events. There was no correlation between the TPMT activity and the development of AZA-induced adverse events. The direct health care costs for group 1 ( $\$ 300.11$ per patient) were lower than in group 2 ( $\$ 348.87$ per patient).

CONCLUSION: The prospective assessment of TPMT enzyme activity before initiating AZA therapy in IBD patients incurred additional cost and did not predict AZA-induced toxicity.

Key Words: 6-mercaptopurine; Azathioprine; Crohn's disease; Health economics; Inflammatory bowel disease; Mesalamine; Pharmacoeconomics; Thiopurine methyltransferase (TPMT); Ulcerative colitis

\section{La détermination de l'activité de l'enzyme thiopurine méthyltransférase avant le traitement d'une maladie inflammatoire de l'intestin à l'azathioprine: L'effet sur le coût et les effets néfastes}

HISTORIQUE : L'azathioprine (AZA) utilisée dans le traitement des maladies inflammatoires de l'intestin (MII) est métabolisée par la thiopurine méthyltransférase (TPMT). L'accumulation de métabolites individuels varie parce que les humains affichent un polymorphisme génétique à l'expression de la TPMT. Des carences en TPMT provoquent une accumulation des métabolites toxiques, suivie d'une neutropénie et d'une inflammation hépatique. Des inquiétudes relatives envers une toxicité aiguë entraînent souvent un dosage insuffisant, de fréquents examens de surveillance et des visites rapprochées.

OBJECTIF : Déterminer si l'évaluation de l'activité de la TPMT avant l'administration d'AZA permettrait de prédire une toxicité aiguë et d'ainsi réduire les coûts de santé reliés au dépistage biochimique et à la prise en charge des effets néfastes provoqués par l'AZA.

MÉTHODOLOGIE : Avant le traitement à l'AZA, 29 patients atteints d'une MII ont été divisés de manière aléatoire et prospective dans l'un des deux groupes suivants : le groupe 1, pour lequel aucun titrage de la TPMT n'a été effectué, a commencé par prendre $1 \mathrm{mg} / \mathrm{kg} / \mathrm{jour}$ d'AZA puis a été redosé toutes les deux semaines pour atteindre une dose cible de $2,5 \mathrm{mg} / \mathrm{kg} /$ jour, et le groupe 2, qui a subi des titrages de TPMT, a commencé le traitement à l'AZA à la dose cible de $2,5 \mathrm{mg} / \mathrm{kg} / \mathrm{jour}$. Pour les deux groupes, la formule sanguine et les enzymes hépatiques ont été surveillés toutes les semaines pendant six semaines, puis tous les mois. Des examens supplémentaires et des interventions de santé ont été entreprises, au gré du médecin traitant.

RÉSULTATS : Sur les 29 patients à l'étude, 15 ont été placés aléatoirement dans le groupe 1, et 14, dans le groupe 2. Les caractéristiques démographiques et l'activité de la maladie étaient similaires dans les deux groupes. Le suivi moyen était de 7,1 mois (fourchette de 3,5 à 10,7 mois). Huit patients du groupe 1 et six du groupe 2 ont dû abandonner le traitement en raison d'effets néfastes de l'AZA. On ne remarquait aucune corrélation entre l'activité de la TPMT et l'apparition d'effets néfastes de l'AZA. Les coûts de santé directs du groupe 1 (300,11 \$ par patient) étaient inférieurs à ceux du groupe 2 (348,87 \$ par patient).

CONCLUSION : L'évaluation prospective de l'activité de l'enzyme TPMT avant le début du traitement à l'AZA chez les patients atteints d'une MII ont ajouté des coûts et n'ont pas permis de prédire la toxicité de l'AZA.

${ }^{1}$ Division of Gastroenterology, ${ }^{2}$ Department of Laboratory Medicine, and ${ }^{3}$ Department of Public Health, University of Alberta, Edmonton, Alberta Correspondence: Dr Richard N Fedorak, Division of Gastroenterology, University of Alberta, Suite 205, College Plaza,

8215-112 Street, Edmonton, Alberta T6G 2C8. Telephone 780-492-6941, fax 780-492-8121, e-mail Richard.Fedorak@ualberta.ca

Received for publication August 26, 2004. Accepted January 3, 2005 
$\mathrm{A}^{2}$ zathioprine (AZA) and 6-mercaptopurine (6-MP) are purine analogues that interfere with nucleic acid metabolism and cell proliferation, and both drugs have immunosuppressive properties (1). Both have been shown to be effective for the induction and maintenance of remission in cases of corticosteroid-dependent or corticosteroid-resistant inflammatory bowel disease (IBD) and in the management of fistulizing Crohn's disease (CD) (2-6). A meta-analysis has shown that $56 \%$ of patients with active CD treated with AZA/6-MP experienced either improvement in their disease state or induction of remission (6). The same analysis showed that $67 \%$ of CD patients with quiescent disease who were treated with AZA/6-MP maintained remission. However, AZA/6-MP use is limited by its short-and long-term toxicities $(7,8)$. Adverse effects caused by AZA/6-MP include leukopenia, bone marrow suppression, hepatotoxicity, pancreatitis and nonspecific side effects such as nausea, vomiting, skin rash, myalgia and fever. The major limiting side effect of AZA/6-MP is myelosuppression. Approximately $10 \%$ of patients with IBD who are treated with AZA/6-MP develop side effects (7). Concern over acute myelosuppression and short-term toxicity frequently leads to the initiation of nontherapeutic dosing regimens and frequent monitoring tests and visits.

The effects of AZA/6-MP are mediated via the drug's intracellular conversion to thiopurine nucleotide metabolites, which are incorporated into cellular nucleic acids, a process which leads to inhibition of de novo purine synthesis (1). As shown in Figure 1, AZA is rapidly converted to 6-MP via nonenzymatic processes, after which 6-MP may be catabolized to the inactive metabolite, 6-methylmercaptopurine (6-MMP), or anabolized to the active metabolites, 6-thioguanine nucleotides (6-TG) and 6-MMP ribonucleotides, via competing pathways. The methylation of 6-MP to 6-MMP ribonucleotides is catalyzed by thiopurine methyltransferase (TPMT) $(1,9)$.

Wide individual differences in TPMT activity have been observed; the differences are largely due to a common genetic polymorphism (10). The frequency distribution of TPMT activity is trimodal: one in 300 individuals have low or absent enzyme activity, approximately $11 \%$ have intermediate activity, and approximately $89 \%$ have normal to high enzyme activity. Enzyme activity is expressed in a Mendelian fashion: a single genetic locus with two alleles, $\mathrm{TPMT}^{\mathrm{L}}$ for low activity and $\mathrm{TPMT}^{\mathrm{H}}$ for high activity, thereby producing the trimodal distribution. Studies have shown that the variable expression of TPMT contributes to the myelotoxicity seen with AZA use (11-13), and that low TPMT status may warn of early bone marrow toxicity, especially within the first four months after the initiation of purine analogue treatment (13). As a result of the competitive pathways setup, a reciprocal relationship exists between TPMT activity and the formation of cytotoxic 6-TG nucleotide metabolites. The lower the inherited TPMT activity, the more 6-MP is available for conversion to toxic thiopurine nucleotide metabolites and the higher the myelotoxicity. In TPMT-deficient patients, high concentrations of 6-TG nucleotides accumulate in hematopoietic tissue, thereby contributing to toxicity $(11,13)$. In the case of IBD, increased 6-TG levels may correlate positively with increased clinical responses and leukopenia $(14,15)$. The accumulation of the end products of TPMT activity, including 6-MMP nucleotide metabolites, has been implicated as a cause of hepatotoxicity (16).

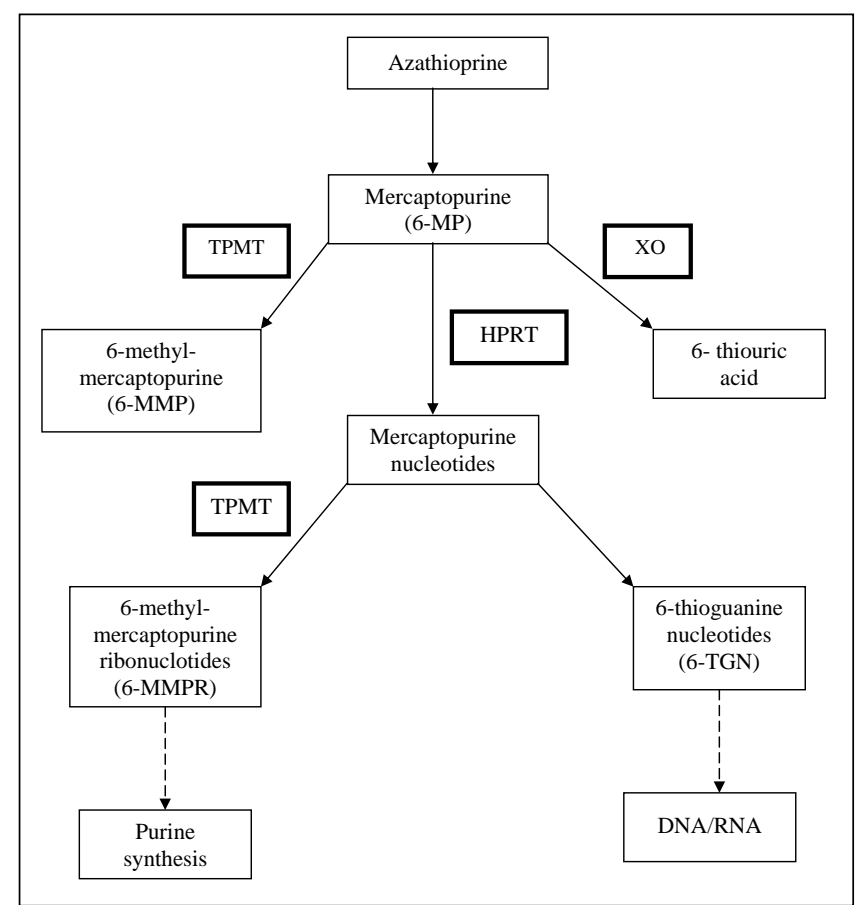

Figure 1) Azathioprine drug metabolism. HPRT Hypoxanthine phosphoribosyl transferase; TPMT Thiopurine methyltransferase; XO Xanthine oxidase

Clinically, TPMT activity can be measured using the red blood cell TPMT assay, which reveals TPMT activity in leukocytes, and in liver and kidney cells (16-18). Various mutant alleles have been identified using polymerase chain reaction techniques, and one study has shown a 98\% concordance between TPMT genotype and TPMT phenotype as determined by the red blood cell assay $(19,20)$.

In the management of IBD through AZA treatment, patients are normally started on a low dose of AZA combined with frequent monitoring of blood cell counts, and AZA doses are titrated to therapeutic levels over many months. The extended titration process is primarily used to identify adverse events. Given the positive correlation between phenotypes and TPMT activity, it seems possible that if the TPMT activity were known at the start, AZA might be prescribed at higher initial doses for certain patients, and less frequent blood count monitoring in the case of these high-expression patients might decrease direct health care costs.

We therefore sought to determine whether the assessment of TPMT activity before administration of AZA would predict toxicity and could therefore be used to reduce the costs related to the standard biochemical screening for, and management of, AZA-induced adverse events.

\section{METHODS}

\section{Patient population and laboratory assessment}

The present study was performed between September 2002 and August 2003, and was approved by the Health Research Ethics Board at the University of Alberta, Edmonton, Alberta. Twentynine patients aged 12 years and older with either CD (23 patients) or ulcerative colitis (six patients) who were starting AZA treatment were recruited for this randomized prospective study. Patients who had received a blood transfusion within 90 days, or who had leukopenia (white blood cell count less than $4 \times 10^{8} / \mathrm{L}$ ), 
TABLE 1

Patient demographics

\begin{tabular}{lcc}
\hline & $\begin{array}{c}\text { Group 1 } \\
(\mathbf{n = 1 5 )}\end{array}$ & $\begin{array}{c}\text { Group 2 } \\
(\mathbf{n = 1 4 )}\end{array}$ \\
\hline $\begin{array}{l}\text { Sex, } \mathrm{n} \\
\text { Male }\end{array}$ & 11 & 4 \\
Female & 4 & 10 \\
Age, years (mean $\pm \mathrm{SD}$ ) & $31.4 \pm 12.5$ & $40.6 \pm 16.4$ \\
(range 12 to 58) & (range 15 to 80) \\
Disease, $\mathrm{n}$ & \\
$\quad$ Crohn's disease & 12 & 11 \\
Ulcerative colitis & 3 & 3 \\
Indication for azathioprine therapy, $\mathrm{n}$ & & \\
$\quad$ Postsurgery remission & 3 & 0 \\
$\quad$ Steroid-dependant disease & 12 & 14 \\
Concomitant medications, $\mathrm{n}$ & & 11 \\
Corticosteroids & 6 & 4 \\
5-Aminosalicylates & 3 &
\end{tabular}

Group 1: No thiopurine methyltransferase (TPMT) assay before initiation of azathioprine; Group 2: TPMT assay performed before initiation of azathioprine

thrombocytopenia (platelets less than 100,000/L), pancytopenia, elevated liver enzymes (alanine aminotransferase [ALT] or aspartate aminotransferase [AST] or gamma-glutamyltransferase [GGT] greater than $2 \times$ upper limit of normal), or elevated lipase (greater than $2 \times$ upper limit of normal) or who were on allopurinol were excluded from the study. The patients' reasons for starting immunosuppressive treatment included steroid dependency (26 patients) and maintenance of remission after surgical resection (three patients). Table 1 summarizes the characteristics of the patients at the time of randomization.

Before starting AZA, the 29 patients were prospectively randomized to one of two groups. Group $1(n=15)$ did not have the TPMT assay performed; they were started on AZA at $1 \mathrm{mg} / \mathrm{kg} / \mathrm{day}$, and the dose was titrated upwards by $50 \mathrm{mg}$ every two weeks to a target dose of $2.5 \mathrm{mg} / \mathrm{kg} /$ day. Group $2(\mathrm{n}=14)$ had the TPMT assay performed before starting AZA. All 14 patients in group 2 had normal TPMT levels (greater than $9 \mathrm{nmol} / \mathrm{mL}$ red blood cells) and started AZA at the target dose of $2.5 \mathrm{mg} / \mathrm{kg} / \mathrm{day}$.

At randomization, all patients in both groups had a complete blood count with differential, ALT, AST, GGT and lipase levels, to ensure that they had normal values before randomization and initiation of AZA therapy. While the patients were on AZA, complete blood count with differential, ALT, AST and GGT were measured weekly for six weeks and then monthly thereafter as a safety measure. Any additional tests or health care interventions, including AZA dose adjustments and laboratory investigations, were undertaken at the discretion of the attending gastroenterologist, who was kept blinded as to the group assignment and TPMT assay results. Patients' disease courses were followed from the time of their enrollment in the study to the study completion date.

Direct health care costs, including the cost of the TPMT assay, scheduled laboratory investigations and nonscheduled diagnostic investigations were recorded. The TPMT assay was valued at $\$ 50.00$, and the local regional laboratory and provincial billing guidelines were used to determine the value of laboratory and diagnostic investigations (Table 2). Telephone calls to nurses and visits to a physician because of side effects or consequences of AZA treatment were also recorded and valued according to local provincial billing guidelines (Table 2).
TABLE 2

Direct costs for laboratory and diagnostic investigations

\begin{tabular}{lc}
\hline Investigation & Cost (\$) \\
\hline Thiopurine methyltransferase assay* $^{*}$ & 50.00 \\
Complete blood count* $^{*}$ & 15.05 \\
Alanine aminotransferase* $^{*}$ & 3.80 \\
Aspartate aminotransferase* $^{*}$ & 3.48 \\
Gamma-glutamyltransferase $^{*}$ & 3.78 \\
Lipase $^{*}$ & 4.22 \\
Hepatitis A, B and C serology $^{*}$ & 15.00 \\
Phone call with nurse $^{\dagger}$ & 22.50 \\
Family practitioner visit $^{\ddagger}$ & 28.97 \\
Abdominal ultrasound $^{\ddagger}$ & 140.80
\end{tabular}

*Values represent direct cost based on Alberta Provincial Laboratory fee codes; 'Value represents direct (salary plus benefit) cost based on $30 \mathrm{~min}$ time interval; $¥$ Values represent direct reimbursement based on Alberta Medical Association fee codes

\section{Measurement of TPMT activity}

Heparinized blood samples were centrifuged within $2 \mathrm{~h}$ of collection, and the plasma was removed. The erythrocytes were then washed with saline and resuspended in $2 \mathrm{~mL}$ of saline to determine the hematocrit. The cells were then lysed with ice-cold water, cellular debris was removed, and the supernatant was assayed for TPMT activity using the method previously described by Weinshilboum et al (17). Briefly, the erythrocyte lysate was treated with Chelex-100 (BioRad, USA) to remove magnesium before the assay. An aliquot was then added to a reaction mixture containing 6-MP, S-adenosyl-L- $\left[{ }^{14} \mathrm{C}\right]$ methionine, dithiotreitol and allopurinol in a phosphate buffer $(\mathrm{pH}$ 7.5), and the resulting mixture was incubated for $1 \mathrm{~h}$ at $37^{\circ} \mathrm{C}$. The reaction was then stopped by the addition of a borate buffer; the resulting 6-MMP was extracted into isoamyl alcohol and quantitated through scintillation counting of the ${ }^{14} \mathrm{C}$. Results are expressed as nmol of 6-MMP produced per $\mathrm{mL}$ of packed erythrocytes per hour of incubation at $37^{\circ} \mathrm{C}$. If the samples were not assayed immediately, they were stored at $-70^{\circ} \mathrm{C}$. However, all samples were assayed within four days of collection. Repeat analysis of one sample showed an interassay precision of $100 \%$ over the course of the study.

\section{RESULTS}

Of the 29 patients enrolled in the study, 15 were randomized to group 1 and, thus, did not have their TPMT activity determined. The remaining 14 were randomized to group 2, and their TPMT activity tested as normal. The demographics of the groups were similar, as shown in Table 1, except for the difference in sex between the two groups.

Eight patients from group 1 and eight patients from group 2 ( $53 \%$ and $57 \%$, respectively) withdrew from the study (Table 3 ). Five patients in each group withdrew due to intractable clinical symptoms of nausea, vomiting, myalgia, fatigue, leg cramps or headaches. One patient in group 1 developed leukopenia $\left(2.2 \times 10^{9} / \mathrm{L}\right)$ seven months after starting AZA and was withdrawn. Two patients in group 1 developed elevated liver enzymes (ALT $82 \mathrm{U} / \mathrm{L}$, AST $52 \mathrm{U} / \mathrm{L}$ and GGT $165 \mathrm{U} / \mathrm{L}$ and ALT 329 U/L, AST 302 U/L and GGT 503 U/L, respectively) at two weeks and two months after drug initiation, respective$1 y$, and were withdrawn. One patient in group 2 developed clinical pancreatitis (lipase $2912 \mathrm{U} / \mathrm{L}$ ) two weeks after starting the drug and was withdrawn. Two patients in group 2 withdrew from the study at 1 and 3.6 months because the AZA provided no therapeutic effects. Patients in group 1 withdrew at a mean 
TABLE 3

Reasons for withdrawal from the study

\begin{tabular}{lcc}
\hline Reasons for withdrawal & Group 1 (n=8) & Group 2 (n=8) \\
\hline Nausea, vomiting, myalgia, & 5 & 5 \\
$\quad$ fatigue, leg cramps or headaches, $\mathrm{n}$ & & \\
Leukopenia, $\mathrm{n}$ & 1 & 0 \\
Elevated liver enzymes, $\mathrm{n}$ & 2 & 0 \\
Pancreatitis, $\mathrm{n}$ & 0 & 1 \\
No therapeutic effect, $\mathrm{n}$ & 0 & 2 \\
\hline
\end{tabular}

Group 1: No thiopurine methyltransferase assay before initiation of azathioprine; Group 2: thiopurine methyltransferase assay performed before initiation of azathioprine

of $2.7 \pm 2.8$ months (range 0.4 to 8.0 months) after initiation of the drug therapy, while patients in group 2 withdrew at a mean of $1.6 \pm 1.4$ months (range 0.2 to 4.0 months). For the 13 patients still in the study at its termination, mean follow-up was $8.0 \pm 2.3$ months (range 3.5 to 10.7 months).

Evaluation of all direct health care costs revealed that the costs for group 1 ( $\$ 300.31$ per patient) were less that those for group 2 (\$348.87 per patient) (Figure 2$)$. This increased cost in group 2 was almost fully attributable to the cost of the TPMT assay.

To determine whether TPMT assay determination affected the initiation and cost of additional laboratory and diagnostic investigations, the total number of scheduled and nonscheduled hematological and biochemical investigations and phone calls and visits to the nurse/physician were recorded. Group 1 had a significantly higher number of physician/nurse-initiated hematological and biochemical investigations than group 2 (Table 4) $(\mathrm{P}=0.013)$, as a consequence of physicians monitoring for side effects and toxicities. However, this translated into only a small increase in additional laboratory and diagnostic costs, $\$ 39.21$ versus $\$ 37.77$, group 1 versus group 2, respectively. Patients in group 1 initiated a total of nine phone calls to their physicians or nurses to discuss the AZA therapy, while patients in group 2 initiated 11 such calls. Only one additional unscheduled doctor visit occurred in group 1, in a patient presenting with jaundice and hepatitis.

\section{DISCUSSION}

It is well established that 6-MP, and its prodrug AZA, are effective in the treatment of steroid-refractory IBD and in the maintenance of steroid-induced remission. What is less clear, however, is the role of TPMT activity, the key enzyme responsible for the metabolism of AZA into toxic and therapeutic metabolites, in the management of IBD. Specifically, knowing that a patient has sufficient TPMT activity (group 2 in this study) would permit a 'step-in' initiation of full dose AZA on day 1, whereas not knowing the TPMT activity (group 1 in this study) would, in general, necessitate a 'step-up' approach in dosing over several weeks. The present study thus examined whether assessment of TPMT activity before the administration of AZA (subsequently permitting either 'step-in' or 'step-up'

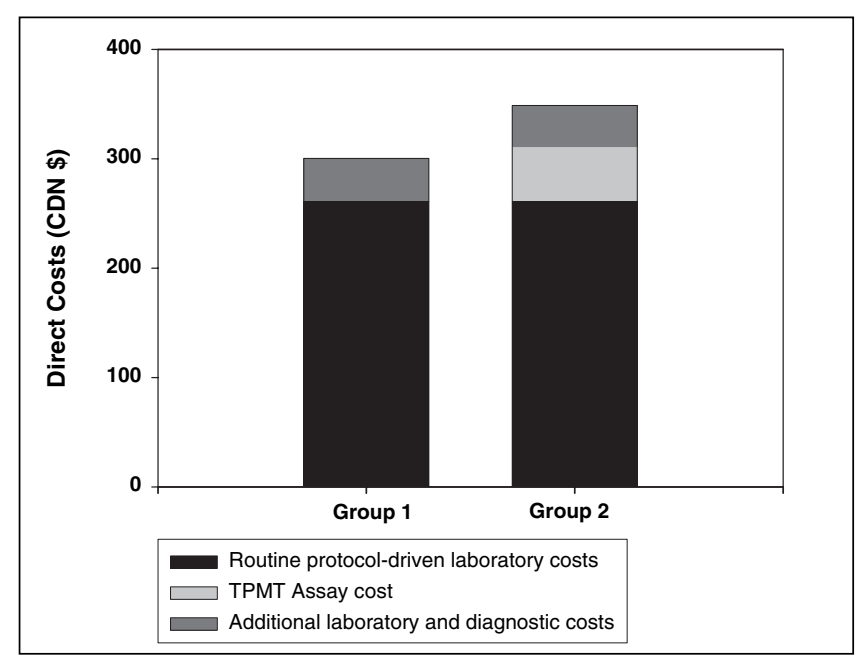

Figure 2) Total direct costs for groups 1 and 2. Routine costs included protocol-defined blood work every week for six weeks, then monthly thereafter for the duration of enrollment in the study. Additional costs included physician-initiated hematological blood tests, biochemical tests, radiological imaging, telephone calls to the physician/nurse and visits to the physician. Group 1: no thiopurine methyltransferase (TPMT) assay before initiation of azathioprine; Group 2: TPMT assay performed before initiation of azathioprine

dosing) would predict acute toxicity and, thus, allow for reduction in health care costs related to biochemical screening for, and management of, AZA-induced adverse events.

Knowing TPMT activity and starting AZA in either a 'stepin' or 'step-up' approach did not alter the number of adverse events related to AZA nor the number of withdrawals from the study. This is likely because most of the adverse events necessitating withdrawal were those that are generally thought to be independent of AZA metabolite levels $(13,16)$. One patient developed leukopenia and two patients developed elevated liver enzymes in the group in which TPMT activity was not initially known (group 1; 'step-up' AZA dosing); however, retrospective testing confirmed normal TPMT activity in these patients. This is consistent with previous reports where myelosuppression and elevated liver enzymes can occur despite normal TPMT genotype and activity $(13,16,18,19)$. Furthermore, these adverse events can occur months or even years after successful dosing with AZA (20). Nevertheless, it is important to point out that this study did not find low TPMT activity in any of its subjects. Identifying a low TPMT activity would predict the $\mathrm{TPMT}^{\mathrm{H}} / \mathrm{TPMT}^{\mathrm{L}}$ or $\mathrm{TPMT}^{\mathrm{L}} / \mathrm{TPMT}^{\mathrm{L}}$ genotype and likely contraindicate the use of AZA. Even though low TPMT activity may abrogate the use of AZA, demonstrating normal TPMT activity before dosing with AZA was not a positive or negative predictor of adverse events.

TPMT activity can be influenced not only by TPMT genotype but by concomitant medications. TPMT activity can be

\section{TABLE 4}

Summary of cost items

\begin{tabular}{lccccc}
\hline Group & $\begin{array}{c}\text { Protocol-defined } \\
\text { hematological and } \\
\text { biochemical investigations (n) }\end{array}$ & $\begin{array}{c}\text { hematological and biochemical } \\
\text { investigations (n) }\end{array}$ & $\begin{array}{c}\text { Physician-initiated } \\
\text { abdominal ultrasound (n) }\end{array}$ & $\begin{array}{c}\text { Patient-initiated } \\
\text { phone calls (n) }\end{array}$ & $\begin{array}{c}\text { Unscheduled physician } \\
\text { visit (n) }\end{array}$ \\
\hline Group 1 & 101 & $10^{*}$ & 1 & 9 & 1 \\
Group 2 & 101 & 5 & 1 & 11 & 0 \\
\hline
\end{tabular}

${ }^{*} P=0.013$ relative to group 2. Group 1: No thiopurine methyltransferase assay before initiation of azathioprine; Group 2: thiopurine methyltransferase assay performed before initiation of azathioprine 
inhibited by sulfasalazine (21), olsalazine (22), balsalazide (23), mesalamine $(21,23)$ and, to a lesser extent, by furosemide, thiazide diuretics and nonsteroidal anti-inflammatory drugs (24). Thus, the concomitant use of mesalamine could lead to increased toxicity. Seven patients in the present study were using mesalamine concomitantly with AZA. None of the patients on mesalamine developed AZA-related adverse events.

In the present study, the prospective assessment of TPMT enzyme activity before the initiation of AZA therapy for patients with IBD in group 2 was associated with increased direct cost $(\$ 348.87$ per patient) compared with group 1 (\$300.11 per patient), in which the TPMT assay was not performed. This increase in cost was almost fully attributed to the cost of the TPMT assay (valued at \$50.00). More importantly, however, was the fact that knowing TPMT activity did not markedly reduce the cost of additional laboratory and diagnostic tests in patients over the duration of the study (group 2; $\$ 37.77$ per patient versus group 1; $\$ 39.21$ per patient). The reason for this cost similarity is the fact that additional testing was predominately driven by adverse events. The adverse events were similar in both groups and also not generally those related to AZA metabolites (Table 3). It is important to note that the majority of the costs in this study were due to the protocoldriven routine laboratory investigations and, thus, were equal in both groups. One could hypothesize that knowing a normal TPMT activity would eliminate the need for routine testing

\section{REFERENCES}

1. Lennard L. The clinical pharmacology of 6-mercaptopurine. Eur J Clin Pharmacol 1992;43:329-39.

2. Willoughby JM, Beckett J, Kumar PJ, Dawson AM. Controlled trial of azathioprine in Crohn's disease. Lancet 1971;2:944-7.

3. Present DH, Korelitz BI, Wisch N, Glass JL, Sachar DB, Pasternack BS. Treatment of Crohn's disease with 6-mercaptopurine. A long-term, randomized, double-blind study. N Engl J Med 1980;302:981-7.

4. Candy S, Wright J, Gerber M, Adams G, Gerig M, Goodman R. A controlled double blind study of azathioprine in the management of Crohn's disease. Gut 1995;37:674-8.

5. Ewe K, Press AG, Singe CC, et al. Azathioprine combined with prednisolone or monotherapy with prednisolone in active Crohn's disease. Gastroenterology 1993;105:367-72.

6. Pearson DC, May GR, Fick GH, Sutherland LR. Azathioprine and 6-mercaptopurine in Crohn disease. A meta-analysis. Ann Intern Med 1995;123:132-42

7. Present DH, Meltzer SJ, Krumholz MP, Wolke A, Korelitz BI. 6-Mercaptopurine in the management of inflammatory bowel disease: Short- and long-term toxicity. Ann Intern Med 1989;111:641-9.

8. Connell WR, Kamm MA, Ritchie JK, Lennard-Jones JE. Bone marrow toxicity caused by azathioprine in inflammatory bowel disease: 27 years of experience. Gut 1993;34:1081-5.

9. Lennard L. Clinical implications of thiopurine methyltransferase optimization of drug dosage and potential drug interaction. Ther Drug Monit 1998;20:527-31.

10. Weinshilboum RM, Sladek SL. Mercaptopurine pharmacogenetics: Monogenic inheritance of erythrocyte thiopurine methyltransferase activity. Am J Hum Genet 1980;32:651-62.

11. Lennard L, Lilleyman JS. Variable 6-mercaptopurine metabolism and treatment outcome in childhood lymphoblastic leukemia. J Clin Oncol. 1989;7:1816-23. Erratum in: J Clin Oncol 1990;8:567.

12. Lennard L, Van Loon JA, Weinshilboum RM. Pharmacogenetics of acute azathioprine toxicity: Relationship to thiopurine methyltransferase genetic polymorphism. Clin Pharmacol Ther 1989;46:149-54.

13. Campbell S, Kingstone K, Ghosh S. Relevance of thiopurine methyltransferase activity in inflammatory bowel disease patients maintained on low-dose azathioprine. Aliment Pharmacol Ther 2002;16:389-98. and, thereby, significantly reduce costs. Unfortunately, this is unlikely to be the case, because this and other studies have demonstrated myelotoxicity and hepatotoxicity in the presence of normal TPMT activity $(19,20)$. Physicians are thus likely to continue to perform hematological and biochemical testing on a regular basis.

None of the patients in the present study were homozygous for TPMT deficiency. It has recently been suggested that TPMT genotyping would be cost-effective in identifying the one in 300 individuals homogenous for TPMT deficiency (25). Indeed, it is this group in whom acute and severe myelosuppression is most frequent and has led to the current clinical practice of subtherapeutic dosing and frequent biochemical monitoring.

The role of prospective TPMT testing, and thus 'step-in' versus 'step-up' therapy, on the efficacy of AZA therapy was not addressed in the present study and is the objective of a multicentre, randomized, controlled trial currently underway (http://www.clinicaltrials.gov/ct/show/NCT00098111). Furthermore, this ongoing clinical trial will provide a larger sample size to substantiate the role of TPMT determination in the prediction of acute AZA adverse events.

In summary, the prospective assessment of a normal TPMT enzyme activity before initiating AZA therapy in IBD patients added additional cost and did not predict AZAinduced toxicity.

14. Lennard L, Lilleyman JS, Van Loon J, Weinshilboum RM. Genetic variation in response to 6-mercaptopurine for childhood acute lymphoblastic leukaemia. Lancet 1990;336:225-9.

15. Cuffari C, Theoret Y, Latour S, Seidman G. 6-mercaptopurine metabolism in Crohn's disease: Correlation with efficacy and toxicity. Gut 1996;39:401-6. Erratum in: Gut 1998;43:301.

16. Dubinsky MC, Lamothe S, Yang HY, et al. Pharmacogenomics and metabolite measurement for 6-mercaptopurine therapy in inflammatory bowel disease. Gastroenterology 2000;118:705-13.

17. Weinshilboum RM, Raymond FA, Pazmino PA. Human erythrocyte thiopurine methyltransferase: Radiochemical microassay and biochemical properties. Clin Chim Acta 1978;85:323-33.

18. Lowry PW, Franklin CL, Weaver AL, et al. Measurement of thiopurine methyltransferase activity and azathioprine metabolites in patients with inflammatory bowel disease. Gut 2001;49:665-70.

19. Lennard L. TPMT in the treatment of Crohn's disease with azathioprine. Gut 2002;51:143-6.

20. Colombel JF, Ferrari N, Debuysere H, et al. Genotypic analysis of thiopurine S-methyltransferase in patients with Crohn's disease and severe myelosuppression during azathioprine therapy. Gastroenterology 2000;118:1025-30.

21. Szumlanski CL, Weinshilboum RM. Sulphasalazine inhibition of thiopurine methyltransferase: Possible mechanism for interaction with 6-mercaptopurine and azathioprine. Br J Clin Pharmacol 1995;39:456-9.

22. Lewis LD, Benin A, Szumlanski CL, et al. Olsalazine and 6-mercaptopurine-related bone marrow suppression: A possible drug-drug interaction. Clin Pharmacol Ther 1997;62:464-75. Erratum in: Clin Pharmacol Ther 2000;67:431.

23. Lowry PW, Szumlanski CL, Weinshilboum RM, Sandborn WJ. Balsalazide and azathioprine or 6-mercaptopurine: Evidence for a potentially serious drug interaction. Gastroenterology 1999;116:1505-6.

24. Lysaa RA, Giverhaug T, Wold HL, Aarbakke J. Inhibition of human thiopurine methyltransferase by furosemide, bendroflumethiazide and trichlormethiazide. Eur J Clin Pharmacol 1996;49:393-6.

25. Marra CA, Esdaile JM, Anis AH. Practical pharmacogenetics: The cost effectiveness of screening for thiopurine s-methyltransferase polymorphisms in patients with rheumatological conditions treated with azathioprine. J Rheumatol 2002;29:2507-12. 


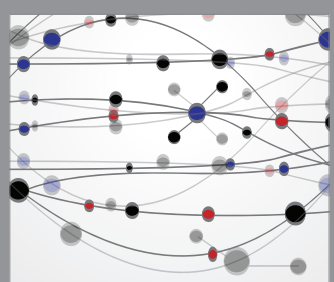

The Scientific World Journal
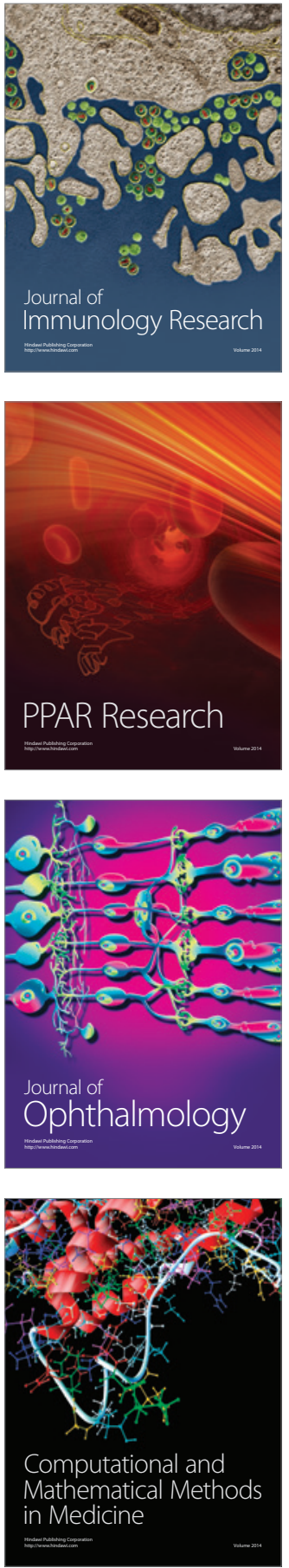

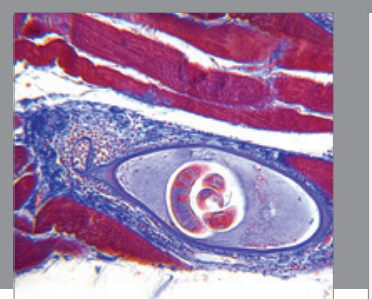

Gastroenterology Research and Practice

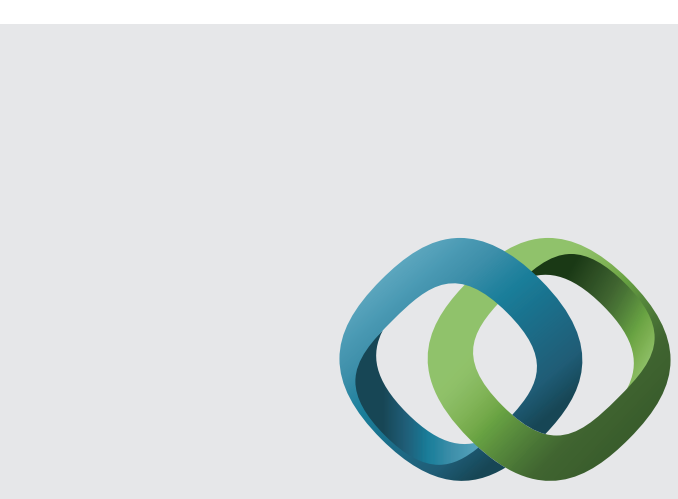

\section{Hindawi}

Submit your manuscripts at

http://www.hindawi.com
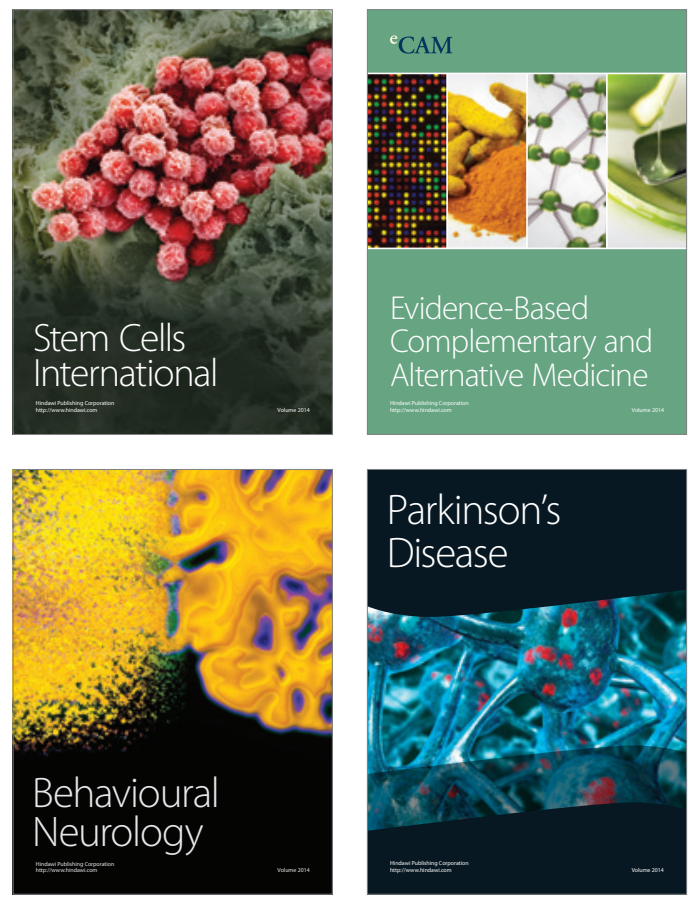
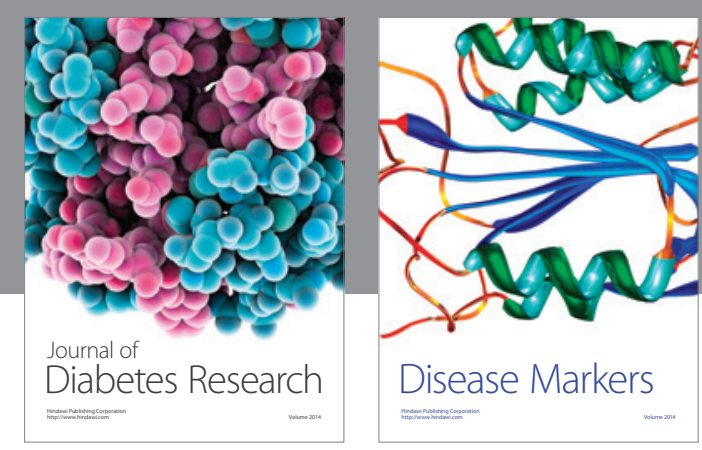

Disease Markers
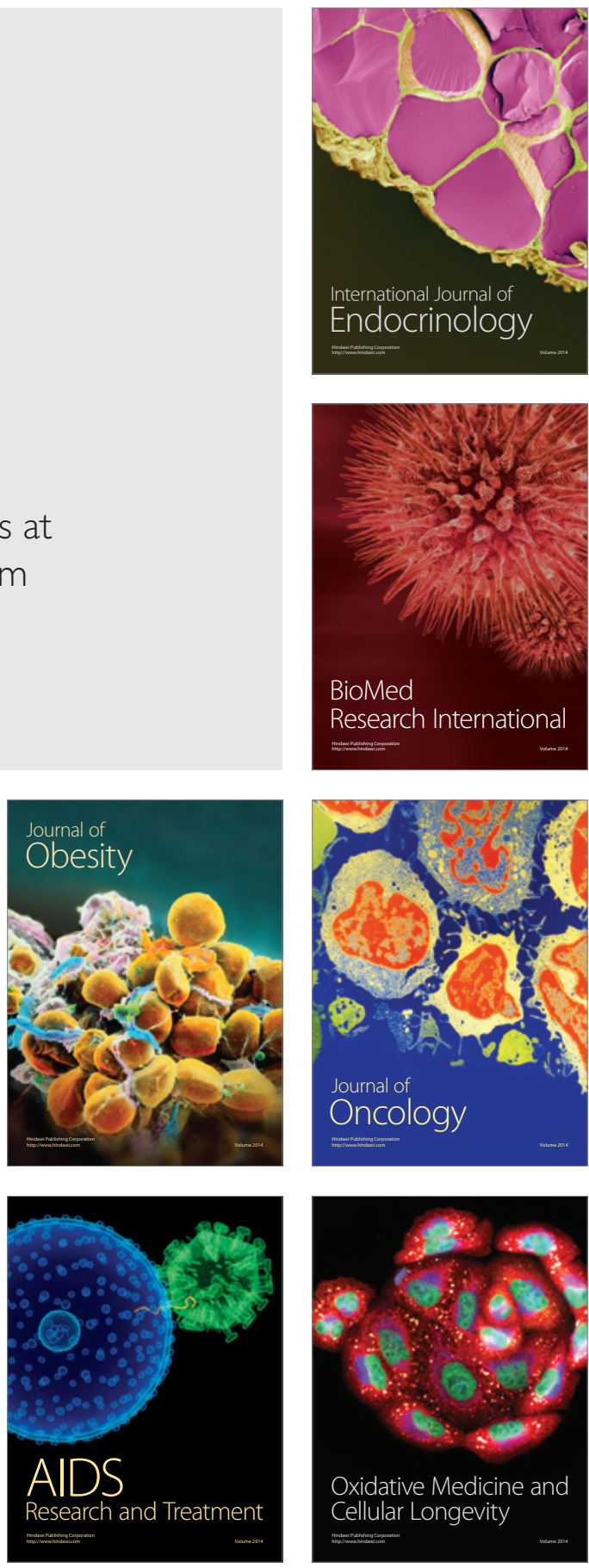